\title{
DEMOGRAPHIC CHARACTERISTICS OF RELAPSING SCHIZOPHRENIC PATIENTS
}

\section{Erika Gustira*, Fathra Annis Nauli, Yufitriana Amir}

Faculty of Nursing, Universitas Riau, Indonesia

\section{Article Information}

Received: 22 January 2020

Revised: 11 October 2021

Accepted: 21 November 2021

\section{*Corresponding Author}

Erika Gustira

fathranauli@lecturer.unri.ac.id

\section{DOI}

10.20884/1.jks.2021.16.3.1374

\begin{abstract}
Schizophrenia is a disease that affects the brain and causes disturbing thoughts, perceptions, emotions, movements, and behavior. Schizophrenic relapses indicate the worsening of symptoms or behaviors and endangers patients and their environment. This study aims to analyze the characteristics of relapsing schizophrenic patients at the Tampan Mental Hospital in Pekanbaru, by using a quantitative descriptive research design. The research sample were 167 respondents who met the inclusion criteria and were recruited by the convenience sampling technique. Then, the data was analyzed by univariate analysis. The results showed that most of the respondents lived with their family members $(50.9 \%)$, were medically diagnosed with paranoia $(72.5 \%)$, and have been diagnosed with schizophrenia for $1-5$ years $(49.1 \%)$. According to the results, for most respondents relapse was caused by treatment (120 respondents or $71.9 \%$ ), whereas genetics is considered the highest predisposing factor for relapse, as seen in 74 respondents (44.3\%), and the highest precipitating factor for relapse is family and socioeconomic condition factor, as seen in 51 respondents (30.5\%). Therefore, it can be concluded that the relapse of schizophrenia in patients is caused by a variety of conditions, thus appropriate treatment, that is, according to the patients' characteristics is required.
\end{abstract}

Keywords: Demographic characteristics; schizophrenia; schizophrenia relapse

\section{INTRODUCTION}

Mental health is a state of well-being in which an individual is aware of their own abilities, can cope with pressure, work productively, and is able to contribute to the community (Indonesia Ministry of Health 2014). Mental health remains one of the significant health problems around the world, including in Indonesia. Mental health problems can happen to anyone, and one type of serious psychiatric disorder is schizophrenia.

The World Health Organization (2016) states that 21 million people have been diagnosed with schizophrenia. It has become the dominant psychiatric disorder compared to other mental health disorders. And while schizophrenia itself is not a deadly disease, it can pose a burden to the government, communities, and families due to declining productivity and major medical expenses. The increase in the number of people with mental disorders could add to state burden and decrease human productivity for the long term (Indonesia Ministry of Health 2016).

A significant increase in schizophrenia in Indonesia occurred between 2013 and 2018, from 1.7\% to 7\%, respectively. In 2018 the proportion of households with family members with schizophrenia was 14\% (Indonesia Basic Health Research 2018) During 2017-2018, the Tampan Hospital found that schizophrenic patients make up the largest proportion of their mental disorder patients (Tampan Mental Hospital, 2018). Relapse rates vary from $50 \%$ to $92 \%$ globally (Zewdu shewangizaw and Roan 2014).

Schizophrenic patients could relapse from various trigger factors. Many factors could influence or cause relapse, such as parenting patterns, medication adherence, and patients' socio-economic factors (Kaunang 2015). Another study revealed that factors that affect relapse among schizophrenic patients were social economic factors, non-adherence to treatment, rough treatment, constant quarrels with siblings, 
prolonged conflict with their spouses, and anger by other family members (Amelia and Zainul 2013).

Data from the Tampan Hospital emergency room showed that schizophrenic relapse visits in January, February, and March 2019 were 124 patients, 133 patients, and 84 patients, respectively (Tampan Mental Hospital 2019). Preliminary studies with 5 patients revealed that 3 of the 5 relapsed patients were male, and 2 patients were between $25-65$ years old. The reasons behind the patients' relapses were medication withdrawal, prolonged stress, and dismissal from the workplace.

Several factors and demographic characteristics may affect relapse among schizophrenic patients. The purpose of this study was to determine the factors and demographic characteristics that affect relapse among schizophrenic patients. Previous studies have only used demographic characteristics variables, therefore this study included clinical characteristic variables such as environment and the patient's own condition.

\section{METHOD}

\section{Study Design}

The study was conducted at the Tampan Mental Hospital in Pekanbaru and occurred from August to December 2019. This study used a descriptive quantitative research design.

\section{Sample}

The population in this study were all schizophrenic patients. This study used a convenience sampling method and involved 167 respondents. The inclusion criteria in this study were as follows: diagnosed as schizophrenic patients, were in-patient and out-patient, and had a relapse history. The exclusion criteria in this study were patients with a history of drug user who subsequently experienced mental disorders and patients who were treated for the first time

\section{Instrument}

Data was collected by using a checklist that was developed by researchers based on a literature review. The data was collected from medical records and the respondents' families.

\section{Data Analysis}

The data was analyzed by a computer program. Data was analyzed by the univariate statistic and was presented by frequency distribution tables and percentages.

\section{Ethical Consideration}

This research has been approved by the Institutional Review Board of the Faculty of Nursing, University of Riau, No: 2162/UN19.5.1.1.10/EP/2019

\section{RESULTS}

A total of 167 respondents joined this study. Most of the respondents were in the age range of 26-35 years old $(32.9 \%)$, male $(71.9 \%)$, graduated elementary school $(31.7 \%)$, of Melayu ethnicity (41.9\%), unemployed (65.9\%), and unmarried $(71.3 \%)$.

Table 1. Demographic characteristics of respondents $(\mathrm{n}=82)$

\begin{tabular}{llcc}
\hline Variable & Category & N & $\%$ \\
\hline Age & $\begin{array}{l}\text { Early teenager (12-16 } \\
\text { years old) }\end{array}$ & 2 & 1.2 \\
& $\begin{array}{l}\text { End teenager (17-25 } \\
\text { years old) }\end{array}$ & 37 & 22.2 \\
\hline
\end{tabular}

\begin{tabular}{|c|c|c|c|}
\hline Variable & Category & $\mathbf{N}$ & $\%$ \\
\hline & $\begin{array}{l}\text { Early adult ( } 26-35 \text { years } \\
\text { old) }\end{array}$ & 55 & 32.9 \\
\hline & $\begin{array}{l}\text { Late adult ( } 36-45 \text { years } \\
\text { old) }\end{array}$ & 54 & 32.3 \\
\hline & $\begin{array}{l}\text { Early elderly ( } 46-55 \text { years } \\
\text { old) }\end{array}$ & 16 & 9.6 \\
\hline & $\begin{array}{l}\text { Late elderly (56-65 years } \\
\text { old) }\end{array}$ & 3 & 1.8 \\
\hline \multirow[t]{2}{*}{ Gender } & Male & 120 & 71.9 \\
\hline & Female & 47 & 28.2 \\
\hline \multirow[t]{5}{*}{ Education } & No school & 26 & 15.6 \\
\hline & Elementary school & 53 & 31.7 \\
\hline & Junior high school & 39 & 23.4 \\
\hline & High school & 38 & 22.8 \\
\hline & College & 11 & 6.6 \\
\hline \multirow[t]{8}{*}{ Ethnic } & Melayu & 70 & 41.9 \\
\hline & Minang & 40 & 24.0 \\
\hline & Jawa & 22 & 13.2 \\
\hline & Batak & 18 & 10.8 \\
\hline & Banjar & 6 & 3.6 \\
\hline & Bugis & 3 & 1.8 \\
\hline & Sunda & 3 & 1.8 \\
\hline & Nias & 5 & 3.0 \\
\hline \multirow[t]{5}{*}{ Employment } & Unemployment & 110 & 65.9 \\
\hline & Farmer & 17 & 10.2 \\
\hline & Self employed & 21 & 12.6 \\
\hline & Housewives & 13 & 7.8 \\
\hline & Government employee & 6 & 3.6 \\
\hline \multirow{3}{*}{$\begin{array}{l}\text { Marital } \\
\text { status }\end{array}$} & Unmarried & 119 & 71.3 \\
\hline & Married & 30 & 18.0 \\
\hline & Widow & 18 & 10.8 \\
\hline
\end{tabular}

Almost all respondents were living with their family (50.9\%), have been diagnosed with paranoid schizophrenia (72.5\%), and have been diagnosed with schizophrenia for 1-5 years (49.1\%). The results also showed that most relapses were caused by medicine withdrawal $(71.9 \%)$, the highest predisposing factor that caused relapses was genetics $(44.3 \%)$, and the highest precipitation factor that causes relapse was the family and socioeconomic factor (30.5\%).

Table 2. Clinical characteristics of respondents $(n=82)$

\begin{tabular}{llcc}
\hline Variable & Category & (n) & $\%$ \\
\hline Living together & Family & 85 & 50.9 \\
& Single parent & 25 & 15.0 \\
& Husband/wife & 12 & 7.2 \\
& Children & 6 & 3.6 \\
& Siblings & 13 & 7.8 \\
& Stay alone & 26 & 15.6 \\
\hline Type of & Paranoid & 121 & 72.5 \\
schizophrenia & Disorganized & 4 & 2.4 \\
& Catatonic & 7 & 4.2 \\
& Undifferentiated & 31 & 18.6 \\
\hline
\end{tabular}




\begin{tabular}{|c|c|c|c|}
\hline Variable & Category & (n) & $\%$ \\
\hline & Residual & 4 & 2.4 \\
\hline \multirow{3}{*}{$\begin{array}{l}\text { Long- } \\
\text { diagnosed } \\
\text { schizophrenia }\end{array}$} & 1-5 Years & 82 & 49.1 \\
\hline & 6-10 Years & 37 & 22.2 \\
\hline & > 10 Years & 48 & 28.7 \\
\hline \multirow{4}{*}{$\begin{array}{l}\text { Recurrence } \\
\text { factor }\end{array}$} & Stress & 26 & 15.6 \\
\hline & Medicine & 120 & 71.9 \\
\hline & Family roles & 8 & 4.8 \\
\hline & Environment & 13 & 7.8 \\
\hline \multirow{4}{*}{$\begin{array}{l}\text { Predisposition } \\
\text { factor }\end{array}$} & Genetic & 74 & 44.3 \\
\hline & $\begin{array}{l}\text { Self-concept } \\
\text { disorder }\end{array}$ & 59 & 35.3 \\
\hline & Family factors & 20 & 12.0 \\
\hline & Social relations & 14 & 8.4 \\
\hline \multirow{5}{*}{$\begin{array}{l}\text { Precipitation } \\
\text { factor }\end{array}$} & Stress & 36 & 21.6 \\
\hline & Environment & 41 & 24.6 \\
\hline & Behavioral & 19 & 11.4 \\
\hline & $\begin{array}{l}\text { Family and } \\
\text { socioeconomic }\end{array}$ & 51 & 30.5 \\
\hline & Losing & 20 & 12.0 \\
\hline
\end{tabular}

\section{DISCUSSION}

Adults often experience difficulties in adjusting to changing conditions. At the age of adulthood, a person's emotions are difficult to control and are more prone to violence (Karabekiroglu et al. 2016). Adults will usually experience emotional stress from early adulthood to their $30 \mathrm{~s}$. This is because during this stage of their life, they will often experience excessive worries about work, career, and family. The individual's inability to deal with these stressors can cause emotional disturbances. So it is not surprising that most of the respondents in this study were early adults.

Most people with schizophrenia are men. This may be because men have lower perception-emotional control abilities than women (Navarra-Ventura et al. 2018). Men often believe that problems are something that must be hidden. This creates an internal struggle as they would be reluctant to seek help and shut themselves off from their surrounding environment. These circumstances contribute to men's higher risk for depression (Andira and Nuralita 2018). Even between men and women that have good mental health, there are still differences in cognition. In terms of emotional processing, women recognize basic emotional facial expressions more accurately and faster than men. Women are also more likely to have better social functioning (Gur et al. 2012). Moreover, in schizophrenic patients, women are better than men in terms of emotional control (Navarra-Ventura et al. 2018).

Most of the population in the Riau Province are ethnically Melayu. This study's results are in line with the Riau Province Government data which showed that Melayu (33.20\%) is the largest ethnicity in Riau Province (Data Riau demographic 2019). Research conducted by Sari and Sirna (2015) stated that the largest ethnic group in their research was the Acehnese, this is in line with the place of research, namely in the Aceh area. So it can be concluded that the most ethnic groups are based on the research area itself.

Employment status affects an individual's socioeconomic status. Having a low economic status or being unemployed

increases an individual's stress level due to their inability to meet their own financial needs (Wardani and Dewi 2018). A person may be unemployed due to traumatic experiences such as difficulty in finding a job, failure to apply for a job, and not being trusted to do a job.

Furthermore, marital status may affect mental health. Unmarried people have a higher risk of experiencing schizophrenia than married people. Married couples need to exchange the ego ideal and the identification of behavior to live peacefully, provide attention, and affection to achieve a meaningful and satisfactory life (Zahnia and Sumekar 2016) According to Zahnia and Sumekar (2016), most of their sampled schizophrenic patients had paranoid symptoms $(40.8 \%)$, of which the main characteristics observed in paranoid schizophrenia are delusions and auditory hallucinations. This is consistent with this study's result where most respondents often talk to themselves due to auditory hallucinations. The longer an individual has been diagnosed with schizophrenia, the higher the relapse frequency. Poor drug adherence, discontinuing treatment when feeling asymptomatic, social class, stigma related to the condition, and family background are factors for relapse in schizophrenic patients (Adebiyi et al. 2018).

Furthermore, schizophrenia is significantly correlated with genetics. Most of the respondents in this study have a family history of schizophrenia. Shenoy et al. (2019) indicated in their research that children of mentally ill parents are more susceptible to emotional and psychological problems.

The patients' living environment is the biggest factor in the success of the rehabilitation and treatment program for schizophrenic patients. The environment that influences the development of a person's personality is their family (Khoshgoftar et al. 2021). Most of the respondents in this study have experienced some form of family pressure, such as having their families restrain them, prohibiting them from leaving the house, domestic violence, lack of care, and lack of control over medication adherence. Therefore, family relationships have an important role in handling cases of schizophrenia.

Fountoukalis et al. (2018) found that the age of parents also affects the formation of their relationship with their children, and the age of parents who are too far away from their children results in the ineffectiveness of parent-child relationships, because children feel they have to take care of parents who are entering old age, so that children feel they have a role as parents for their own parents rather than acting as a child

The family's emotional state could also affect the schizophrenia patients' relapse. Schizophrenic patients who live in very critical, argumentative, and highly emotional families have a higher relapse rate compared to schizophrenic patients that are living with a supporting and caring family.

The limitations of this study are the number of respondents, time constraints, and data collection carried out by research assistants, and research assistants were not fully accompanied by researchers when collecting data.

\section{CONCLUSION AND RECOMMENDATION}

Most schizophrenic patients in this study were in the stage of early adulthood (26-35 years old), male, graduated from elementary school, of Melayu ethnicity, unemployed, unmarried, living together with their families, have paranoid 
schizophrenia, and have been diagnosed for 1-5 years with schizophrenia due to non-adherence to treatment. The predisposing factor for relapse is genetics and the precipitating factor for relapse is family and socioeconomic condition. Therefore, health professionals need to pay attention to these specific characteristics to provide appropriate treatment for these individuals.

\section{ACKNOWLEDGMENT}

I would like to thank my supervisor who always provided direction, the Director of the Tampan Mental Hospital of Pekanbaru, all respondents, my beloved family, the research assistants, and friends of the Nursing Faculty of Riau University B2018.

\section{REFERENCES}

Adebiyi, Munirat Olayinka, Samuel Kolawole Mosaku, Omolola Oladunni Irinoye, and Oyeyemi Olajumoke Oyelade. 2018. "Socio-Demographic and Clinical Factors Associated with Relapse in Mental Illness." International Journal of Africa Nursing Sciences 8(November 2017):149-53. doi: 10.1016/j.ijans.2018. 05.007.

Amelia, Diny Rezki, and Anwar Zainul. 2013. "Relapse in Schizophrenic Patients." Universitas Muhammadiyah Malang 01(1):53-65.

Andira, Siti, and Nanda Sari Nuralita. 2018. "The Effect of Gender Differences on Depression Symptoms in Schizophrenic Patients." Universitas Muhammadiyah Sumatera Utara 3(2):97-108.

Data Riau demographic. 2019. Malay Ethnic Data in Riau. Pekanbaru.

Fountoukalis, K., X. Gonda, M. Siamouli, P. Panagiotidis, K. Moutou, I. Nimatoudis, and S. Kasper. 2018. "Paternal and Maternal Age as Risk Factor for Schizophrenia." International Journal of Psychiatry in Clinical Practice 22(3):170-76.

Gur, RC, J. Richard, and ME Calkins. 2012. "Age Group and Sex Differences in Performance on a Computerized Neurocognitive Battery in Children Age 8-21." Neuropsychology 26(2):251-65.

Indonesia Basic Health Research. 2018. Proportion of Schizophrenic Mental Disorders.

Indonesia Ministry of Health. 2014. Indonesia Ministry of Health.

Indonesia Ministry of Health. 2016. "The Role of the Family in Supporting the Mental Health of the Community."
Karabekiroğlu, Aytül, Ozan Pazvantoğlu, Koray Karabekiroğlu, Ömer Böke, and Işil Zabun Korkmaz. 2016. "Associations with Violent and Homicidal Behaviour among Men with Schizophrenia." Nordic Journal of Psychiatry 70(4):303-8. doi: 10.3109/0803 9488.2015.1109139.

Kaunang, Ireine. 2015. "Relationship between Drug Adherence and Recurrence Prevalence in Schizophrenia Patients." E-Journal Nursing 3(2):1-7.

Khoshgoftar, Marziyeh, Anahita Khodabakhshi-Koolaee, and Mohammad Reza Sheikhi. 2021. "Analysis of the Early Mother-Child Relationship in Schizophrenic Patients." International Journal of Social Psychiatry (30). doi: 10.1177/0020764021991186.

Navarra-Ventura, Guillem, Sol Fernandez-Gonzalo, Marc Turon, Esther Pousa, Diego Palao, Narcis Cardoner, and Merce Jodar. 2018. "Gender Differences in Social Cognition: A Cross-Sectional Pilot Study of Recently Diagnosed Patients with Schizophrenia and Healthy Subjects." Canadian Journal of Psychiatry 63(8):53846. doi: 10.1177/0706743717746661.

Sari, H., and W. Sirna. 2015. "Predisposition Factors for Schizophrenic Patients in the Aceh Mental Hospital Clinic." Indonesian Journal for Health Sciences 4(2):12-20.

Shenoy, S., G. Desai, and G. Venkatasubramainan. 2019. "Parenting in Mothers with Schizophrenia and Its Relation to Facial Emotion Recognition Deficits-a Case-Control Study." Asian Journal of Psychiatry 40(0):55-59.

Tampan Mental Hospital. 2019. Inpatient Visit Data. Pekanbaru.

Wardani, Ice Yulia, and Fajar Apriliana Dewi. 2018. "Quality of Life of Schizophrenic Patients Is Perceived through Self-Stigma." Indonesian Nursing 21(1):17-26.

World Health Organization. 2016. Retrieved from Schizophrenia.

Zahnia, Siti, and Dyah Wulan Sumekar. 2016. "Epidemiology Study of Schizophrenia." University of Lampung Medical Faculty 5(5):160-66.

Zewdu shewangizaw, Weret, and mukherjee Roan. 2014. "Prevalence of Relapse and Associated Factors in Patient with Schizophrenia at Amanuel Mental Specialized Hospital, Addis Ababa, Ethiopia: Institution." IMSEAR 2(2):184-92. 